\title{
Glycerol as a cryoprotectant agent to the entomopathogenic nematodes Heterorhabditis spp. and Steinernema spp.
}

\author{
Glicerol como agente crioprotetor dos nematoides \\ entomopatogênicos Heterorhabditis spp. e Steinernema spp.
}

\author{
Bruna Aparecida Guide ${ }^{*}$; Viviane Sandra Alves ${ }^{2}$; Thiago Augusto Paes Fernandes ${ }^{3}$; \\ Fábio Pinhatari Ferreira ${ }^{4}$; Pedro Manuel Oliveira Janeiro Neves ${ }^{5}$
}

\begin{abstract}
The difficulty of storage and conservation of entomopathogenic nematodes (EPNs) is one of the major obstacles for the expansion of its use in the control of biological pest and in the maintenance of collections of these organisms. The objective of this study was to evaluate cryopreservation as a storage and conservation method for EPNs, using glycerol as cryoprotectant. Infective juveniles (IJs) of the species Heterorhabditis amazonensis (RSC 05), H. bacteriophora (HP88), Steinernema feltiae (Sn) and $S$. carpocapse (IBCB-n02) were subjected to the following treatments: (A) immersion in glycerol at different concentrations (10,13 and 15\%); (B) different exposure times of the isolates to glycerol (24 and 48 hours); and (C) two freezing times in liquid nitrogen (LN) at $-196{ }^{\circ} \mathrm{C} \mathrm{(24} \mathrm{and} 168$ hours). Each treatment was replicated four times, and the design was completely randomized in a factorial $3 \times 2 \times 2$ (glycerol concentrations $\mathrm{x}$ glycerol exposure time $\mathrm{x}$ freezing time in LN). IJs survival was evaluated after each exposure time to glycerol and freezing time in LN. Data were subjected to analysis of variance, and means were compared by the Tukey test. S. feltiae and S. carpocapse survived when exposed to glycerol at 10, 13 and 15\% for 24 and 48 hours. After storage in LN for 24 and 168 hours, only S. feltiae survived when exposed to glycerol for 48 hours at concentrations of 10, 13 and 15\%, with 40.5; 58.2; and $57.7 \%$ survival, respectively. S. feltiae was able to infect Galleria mellonella larvae after freezing. However, for the freezing time of 168 hours, $90 \%$ reduction in infectivity was observed.
\end{abstract}

Key words: Storage. Biological control. Cryopreservation. Liquid nitrogen.

\section{Resumo}

A dificuldade de armazenamento e conservação de nematoides entomopatogênicos (NEPs) é um dos principais obstáculos para ampliar seu uso no controle biológico de pragas bem como na manutenção de coleções destes organismos. O objetivo deste estudo foi avaliar a criopreservação como método de armazenamento e conservação de NEPs utilizando o glicerol como crioprotetor. Juvenis infectantes (JIs) das espécies Heterorhabditis amazonensis (RSC 05), H. bacteriophora (HP88), Steinernerma feltiae ( $\mathrm{Sn}$ ) e S. carpocapsae (IBCB-n02) foram submetidos aos seguintes tratamentos: (A) imersão em glicerol em diferentes concentrações (10, 13 e 15\%), (B) diferentes tempos de exposição dos isolados ao glicerol (24 e 48 horas) e (C) dois tempos de congelamento em nitrogênio líquido (NL) a $-196{ }^{\circ} \mathrm{C}$

\footnotetext{
${ }^{1}$ Discente do Curso de Doutorado em Agronomia, Universidade Estadual de Londrina, UEL, Londrina, PR, Brasil. E-mail: bruhguide@gmail.com

${ }^{2}$ Prof $^{\mathrm{a}} \mathrm{Dr}^{\mathrm{a}}$, Departamento de Biologia, Universidade Estadual do Norte do Paraná, UENP, Cornélio Procópio, PR, Brasil. E-mail: vivialves@uenp.edu.br

3 Biólogo, Bolsista do Consórcio Pesquisa Café, UEL, Londrina, PR, Brasil. E-mail: thiagouenp@gmail.com

${ }^{4}$ Discente do Curso de Graduação em Agronomia, UEL, Londrina, PR, Brasil. E-mail: seefloydplay@hotmail.com

${ }_{5}$ Prof. Dr., Departamento de Agronomia, UEL, Londrina, PR, Brasil. E-mail: pedroneves@uel.br

* Author for correspondence
} 
(24 e 168 horas). Cada tratamento teve quatro repetições e o delineamento foi inteiramente casualizado em esquema fatorial $3 \times 2 \times 2$ (concentrações de glicerol x tempo de exposição ao glicerol x tempo de congelamento). A sobrevivência dos JIs foi avaliada após cada tempo de exposição ao glicerol e tempo de congelamento em NL, e os dados submetidos à análise de variância e as médias comparadas pelo teste de Tukey. S. feltiae e $S$. carpocapse sobreviveram quando expostos ao glicerol a 10,13 e $15 \%$ por 24 e 48 horas. Após armazenamento em NL por 24 e 168 horas, somente $S$. feltiae sobreviveu quando exposto ao glicerol por 48 horas nas concentrações de 10, 13 e 15\%, com 40,5; 58,2; 57,7\% de sobrevivência respectivamente. S. feltiae foi capaz de infectar lagartas de Galleria mellonella após o congelamento, entretanto, para o tempo de 168 horas de congelamento foi observada uma redução de $90 \%$ na infectividade.

Palavras-chave: Armazenamento. Controle biológico. Criopreservação. Nitrogênio líquido.

\section{Introduction}

Entomopathogenic nematodes (EPNs) of Steinernema and Heterorhabditis genera have potential for biological control of several insects pests species (GREWAL etal., 2001). Characteristics such as specificity, virulence, compatibility with other entomopathogens and chemical products, ability to displace in search of the host, combined with the fact that they are harmful to vertebrates and plants, besides the possibility of in vivo and in vitro production, are factors which emphasize the importance of these control agents in pest management programs (FUGA et al., 2012).

However, the difficulty of storing and maintaining these entomopathogens is the main obstacle for the expansion of its use in biological control (ANDALÓ et al., 2010), and for collections maintenance. EPNs storage can be carried out in aqueous suspensions or wet surfaces, such as sponges and other synthetic substrates (FUGA et al., 2012). Nevertheless, there are some disadvantages for storage in liquid medium, since the lack of aeration and the suitability of temperature for each species influence survival, mobility and infectivity of these organisms (ALMENARA et al., 2012; ANDALÓ et al., 2005, 2010; GLAZER, 2002). This type of storage requires constant management of isolates, which demands more resources and labor.

Besides liquid media, there are inert compounds with specific function of enriching preservation, such as alginate and fluid gel, which have physical traps or metabolic inhibitors that decrease EPNs mobility, or reduce their metabolism (ALMENARA et al., 2012). Other substrates which may also increase the useful life of these entomopathogens by reducing the metabolism and immobilization are: clay, polyurethane sponge, polyacrylamide gels and granules (ANDALÓ et al., 2010; SHAPIRO-ILAN et al., 2006; GREWAL, 2000). However, microbial contaminants and changes in the chemical properties that comprise the storage medium may influence its quality, which affects the viability of EPNs in these substrates (ANDALÓ et al., 2006, 2010; GLAZER, 2002; GREWAL, 2000; KAYA; STOCK, 1997).

On the other hand, cryopreservation in liquid nitrogen - LN $\left(-196{ }^{\circ} \mathrm{C}\right)$, which consists in decreasing the temperature in order to reduce cellular metabolism, and consequently preserve cells or tissues for long periods and enable resumption of normal development after storage (PEGG, 2007) may be a viable alternative for the long-term conservation of entomopathogenic nematodes. Yet, it should be considered that the use of freezing in LN has been successfully used both in human reproductive medicine and in animal breeding, either through the cryopreservation of germ cells, or through embryo cryopreservation (CALEGHIANI et al., 2008; MAHMOUD et al., 2010).

There are studies on cryopreservation as storage method with other helminths, such as those carried out by James (1985), and Triantaphyllou and McCabe (1989), who evaluated cryopreservation for storing pathogenic nematodes, such as Meloidogyne spp. Regarding EPNs cryopreservation in liquid nitrogen, few studies are found in the literature. 
However, Ohba et al. (1989), Popiel and Vasquez (1991), Curran et al. (1992), and Nugent et al. (1996) attributed the success of this technique to the exposure time of nematodes to the cryoprotectant, as well as to the cryoprotectant's concentration, and to the thawing speed of the isolates. This was also evidenced by Castro et al. (2011), who emphasize that the efficiency of the cryoprotectant may vary in function of the parameters previously exposed.

There is the hypothesis that entomopathogenic nematodes can survive cryopreservation in liquid nitrogen and that there are differences regarding the type, the concentration and the exposure time to cryoprotectants for different species and strains.

Thus, the aim of this study was to evaluate the effect on the viability and infectivity of the species H. amazonensis Andaló, Nguyen and Moino Jr. (RSC 05), H. bacteriophora Poinar
(HP88), S. feltiae Filipjev (Sn), and S. carpocapsae Weiser (IBCB-n02), after exposure to glycerol cryoprotectant in different concentrations and times, and after different freezing times in liquid nitrogen $\left(-196^{\circ} \mathrm{C}\right)$.

\section{Materials and Methods}

Obtainment and maintenance of entomopathogenic nematodes isolates

It was used four species of entomopathogenic nematodes (Table 1) obtained from an inoculum of isolates of the Entomology and Microbial Control Laboratory of the Northern Paraná State University (Cornélio Procópio - PR), and also of the collection of entomopathogenic organisms of the Biological Institute (Campinas - SP).

Table 1. Entomopathogenic nematode species and strains used in cryopreservation tests in liquid nitrogen at $-196{ }^{\circ} \mathrm{C}$, using glycerol as cryoprotectant agent.

\begin{tabular}{ccc}
\hline Strain & Species & Origin \\
\hline RSC05 & Heterorhabditis amazonensis & Benjamin Constant - AM - Brasil \\
HP88 & Heterorhabditis bacteriophora & New Jersey - United States \\
Sn & Steinernema feltiae & Florida - United States \\
IBCB-n02 & Steinernema carpocapsae & Biological Institute - Campinas - SP \\
\hline
\end{tabular}

Isolates were multiplied in vivo, according to the methodology described by Molina and Lopes (2001), using Galleria mellonella (L.) (Lepidoptera: Pyralidae) last instar larvae. After confirmation of infection of larvae by nematodes, the former were transferred to a dry chamber and placed in a climatic chamber at $23 \pm 1{ }^{\circ} \mathrm{C}$ without photoperiod, for five days. After this period, they were placed in White traps (WHITE, 1927) for collection of infective juveniles (IJs), or J3, and were maintained under the same conditions mentioned above. Isolates in aqueous suspension were collected every day and stored for up to seven days after emergence for the use in bioassays.
Exposure of entomopathogenic nematodes to cryoprotectant

The four nematode species were subjected to the following treatments: (A) immersion of IJs in glycerol cryoprotectant at different concentrations $(10,13$ and $15 \%)$, and (B) different exposure times of isolates to glycerol (24 and 48 hours).

IJs suspensions were quantified and standardized in approximately 5,000 IJs/mL. Subsequently, equal amounts of nematode suspension and glycerol (UltraPure $^{\mathrm{TM}}$ Glycerol, Invitrogen) at 20, 26 and $30 \%$ were mixed, and it was obtained final glycerol concentrations of 10, 13 and $15 \%$. Concentrations used were based on the study carried out by Popiel and Vasquez (1991) and Curran et al. (1992). 
Afterwards, IJs suspension with glycerol was distributed in Petri dishes $(10 \mathrm{~mL} /$ dish and four dishes per treatment), and these dishes were placed in a climatic chamber at $23 \pm 1^{\circ} \mathrm{C}$ without photoperiod. After the exposure times of 24 and 48 hours, it was taken a $50 \mu \mathrm{l}$ aliquot of each replication for the counting of alive nematodes and for the viability evaluation. Data were subjected to analysis of variance and to comparison of means by the Tukey test, using the SISVAR statistical software.

For the evaluation of IJs infectivity, $10 G$. mellonella last instar larvae were placed in $9 \mathrm{~cm}$ diameter Petri dishes containing two filter papers at the base. Subsequently, $1 \mathrm{~mL}$ was taken from the IJs suspension with glycerol and distributed on the filter paper. Dishes were kept in a climatic chamber at 23 $\pm 1^{\circ} \mathrm{C}$ without photoperiod for 72 hours, when it was carried out the counting of the dead larvae and the confirmation of death by nematodes infection by means of symptomatology. For the calculation of infectivity percentage, 10 larvae were considered as $100 \%$.

\section{Cryopreservation tests}

Nematodes strains which survived the contact with the cryoprotectants were subjected to freezing in LN. Therefore, $50 \mathrm{~mL}$ of JIs suspensions with glycerol were poured into Whatman $n^{\circ} 42$ paper disc on a Buchner funnel subjected to suction with the aid of a Kitasato connected to a vacuum pump, in order to remove the excess water.

Filter paper containing nematodes was placed in $30 \mathrm{~mL}$ water, distilled to an approximate temperature of $5 \pm 1{ }^{\circ} \mathrm{C}$, in a Petri dish with the base partially immersed in ice for 10 minutes. Soon after, the filter paper was taken out, and the water containing IJs was allowed to drip, and IJ remained in suspension in the dish.

IJs suspension was placed in flat bottom tube and homogenized by vortexing. Afterwards, $3 \mathrm{~mL}$ suspension were placed onto a $2 \mathrm{~cm}$ diameter filter paper disc, in a Buchner funnel, in order to remove excess water by suction. After that, the paper disk with IJs was transferred to a $2 \mathrm{~mL}$ cryovial capped with a silicone ring. Immediately after the disk packaging, cryotubes were immersed in containers with ice. Then, cryotubes were placed in aluminum profile and inserted into a $20 \mathrm{~L}$ cryogenic container with liquid nitrogen.

The whole procedure was individually carried out for each strain (RSC 05, HP88, Sn e IBCB-n02), with two periods of LN incubation (24 and 168 hours). The design was completely randomized in a factorial 3x2x2 (glycerol concentration $\mathrm{x}$ exposure time to glycerol $x$ cryopreservation time) with four replications. There was no control treatment.

After each period of nitrogen incubation (24 and 168 hours), thawing was carried out in order to evaluate survival and infectivity. For this, $2 \mathrm{~mL}$ saline solution were added to a $0.7 \% \mathrm{NaCl}$ at $23{ }^{\circ} \mathrm{C}$ in each cryovial. After that, the volume obtained was placed in a $5.5 \mathrm{~cm}$ diameter Petri dish containing 20 $\mathrm{mL}$ of same saline solution for 24 hours.

Survival was evaluated 24 hours after exposure of EPNs to saline solution, by evaluating the IJs' viability, and it was considered live those IJs which presented movement or reaction to touch with a stylus; and it was considered dead those which were upright and immobile. One hundred IJs were observed in a stereoscopic microscope. Data were subjected to analysis of variance and comparison of means by the Tukey test, and by the SISVAR statistical software. For the evaluation of infectivity, it was used the same methodology described above.

\section{Results and Discussion}

Exposure of entomopathogenic nematodes to glycerol cryoprotectant

The species $H$. amazonensis (RSC05) and $H$. bacteriophora (HP88) did not survive glycerol at any exposure time and in any evaluated concentration. Therefore, only S. feltiae (Sn) and 
S. carpocapsae (IBCB-n02) survived exposure to glycerol, and there was no difference between the evaluated concentrations for both isolates. In relation to the exposure times, the only difference was observed for $S$. carpocapsae isolates, for which the viability observed at 10 and $15 \%$ concentrations differed from that observed at $13 \%$, but did not differ between each other (Table 2).

Table 2. Viability percentage of infective juveniles of Steinernema feltiae and S. carpocapsae after exposure to different concentrations of glycerol for 24 and 48 hours, at $23 \pm 1{ }^{\circ} \mathrm{C}$ without photoperiod.

\begin{tabular}{|c|c|c|}
\hline Steinernema feltiae & \multicolumn{2}{|c|}{ Viability \% } \\
\hline \multirow{2}{*}{ Glycerol Concentration } & \multicolumn{2}{|c|}{ Exposure time to glycerol } \\
\hline & 24 hours & 48 hours \\
\hline $10 \%$ & $74.7 \pm 3.30 \mathrm{Aa}^{*}$ & $78.2 \pm 2.50 \mathrm{Aa}$ \\
\hline $13 \%$ & $77.5 \pm 2.08 \mathrm{Aa}$ & $60.2 \pm 4.11 \mathrm{Aa}$ \\
\hline $15 \%$ & $76.2 \pm 4.64 \mathrm{Aa}$ & $72.7 \pm 5.85 \mathrm{Aa}$ \\
\hline \multicolumn{3}{|l|}{$\begin{array}{l}\text { Valor } F=1.076 \\
C V(\%)=19.64\end{array}$} \\
\hline Steinernema carpocapse & \multicolumn{2}{|c|}{ Exposure time to glycerol } \\
\hline Glycerol concentration & 24 hours & 48 hours \\
\hline $10 \%$ & $87.5 \pm 2.64 \mathrm{Aa}$ & $79.7 \pm 4.78 \mathrm{Ab}$ \\
\hline $13 \%$ & $84.2 \pm 4.34 \mathrm{Aa}$ & $81.7 \pm 3.86 \mathrm{Aa}$ \\
\hline $15 \%$ & $86.2 \pm 5.12 \mathrm{Aa}$ & $78.7 \pm 4.57 \mathrm{Ab}$ \\
\hline $\begin{array}{l}\text { Valor } \mathrm{F}=1.038 \\
\mathrm{CV}(\%)=4.95\end{array}$ & & \\
\hline
\end{tabular}

* Means followed by the same uppercase letter in the column and by the same lowercase letter in the row did not differ by the Tukey test $(\mathrm{P} \leq 0.05)$.

Regarding the infectivity, both $S$. feltiae and $S$. carpocapsae were able to infect and reproduce in $G$. mellonella larvae, when submitted to both glycerol exposure times in all concentrations (Table 3 ).

Popiel and Vasquez (1991) evaluated $S$. carpocapsae and $H$. bacteriophora exposed to $22 \%$ glycerol for 24 hours, and observed 91.6\% and $28.6 \%$ survival, respectively, and these values are higher than those observed in the present study. The authors also observed that $H$. bacteriophora IJs were more sensitive to glycerol exposure than $S$. carpocapsae, which is a fact also observed in this study, since there was no survival for both species of the Heterorhabditis genus. According to the authors, heterorhabditis survive only in lower cryoprotectant concentrations, since they are more susceptible to the toxic effect of glycerol.
Curran et al. (1992) evaluated the viability of different species to glycerol exposure, and established the best concentrations and exposure times for each species: S. carpocasae - $18 \%$ concentration, and 24 hours exposure; S. feltiae $13.8 \%$ concentration, and 72 hours exposure; and $H$. bacteriophora $-17 \%$ concentration, and 72 hours exposure. These concentrations and times presented the best results, differing from those obtained in this work. The authors also evaluated the infectivity of the same isolates and found that both were able to infect and reproduce in $G$. mellonella, unlike what was observed in this study, since only $S$. carpocapse and $S$. feltiae showed infectivity after exposure to glycerol. 
Table 3. Percentage of infectivity of Steinernema feltiae and Steinernema carpocapsae in Galleria mellonella after exposure to glycerol at different concentrations and time.

\begin{tabular}{lcc}
\hline Steinernema feltiae & \multicolumn{2}{c}{ Exposure time to glycerol } \\
\hline \multirow{2}{*}{ Glycerol concentrations } & 24 hours & 48 hours \\
$10 \%$ & $90 \%$ & $100 \%$ \\
$13 \%$ & $80 \%$ & $80 \%$ \\
$15 \%$ & $90 \%$ & $100 \%$ \\
\hline Steinernema carpocapse & \multicolumn{2}{c}{ Exposure time to glycerol } \\
\hline Glycerol concentrations & 24 hours & 48 hours \\
$10 \%$ & $100 \%$ & $40 \%$ \\
$13 \%$ & $100 \%$ & $100 \%$ \\
$15 \%$ & $80 \%$ & $90 \%$ \\
\hline
\end{tabular}

Ohba et al. (1989), when evaluating the viability of $S$. feltiae exposed to $30 \%$ glycerol for 24 and 48 hours, obtained values of 67.8 and $78.6 \%$, respectively, which are similar to those found in the present study at lower concentrations. According to the authors, glycerol was not harmful to the isolates, although they observed that nematodes were shrunken and immobile, which was not observed in this study, since nematodes were mobile.

According to Castro et al. (2011), all cells are able to metabolize glycerol and there is no toxicity information regarding it. However, the literature reports that glycerol may affect physical events in the cytoplasm, such as cytoplasmic organization, change in the permeability and stability of the lipid bilayer, acting directly on the glycocalyx and on the membrane proteins (HAMMERSTEDT; GRAHAM, 1992). Such changes may affect cellular homeostasis, causing permanent changes in the cells, and leading to decrease in infectivity, or even IJs' death.

Based on the presented results, it can be inferred that the survivability of nematodes to possible changes in the cytoplasm caused by glycerol varies between species and between strains of the same species, and that this may be influenced by both the concentration and the exposure time to glycerol (Table 2).

\section{Cryopreservation tests}

In cryopreservation test, it was found that $S$. feltiae ( $\mathrm{Sn}$ ) did not survive freezing at any evaluated time when exposed to glycerol for 24 hours, which indicates that 24 hours exposure was not sufficient for the cryoprotectant to penetrate the IJs' cells.

However, survival was observed for $S$. feltiae when exposed to glycerol for 48 hours, and when frozen for 24 hours and 168 hours in $\mathrm{LN}$ at $-196^{\circ} \mathrm{C}$. For the evaluation with 24 hours freezing, survival at $13 \%$ and $15 \%$ concentrations did not differ between each other, with 58.2 and $57.7 \%$ survival, respectively, but it was high when compared to the nematode treated with $10 \%$ glycerol, whose survival was $40.5 \%$ (Table 4 ).

Although S. carpocapsae survived exposure to cryoprotectants, it did not survive cryopreservation. These results were different from those obtained in the study carried out by Popiel and Vasquez (1991), who observed $95 \%$ survival of $S$. carpocapsae IJs after 24 hours exposure in $22 \%$ glycerol, and 24 hours cryopreserved in LN. The authors also evaluated $H$. bacteriophora survival after storage in $\mathrm{LN}$, and results varied between $15 \%$ and $65 \%$, which were different from those found in this work. 
Table 4. Steinernema feltiae viability percentage after cryopreservation in liquid nitrogen $\left(-196{ }^{\circ} \mathrm{C}\right)$ exposed to glycerol at different concentrations and times.

\begin{tabular}{lcc}
\hline 24 hours freezing & \multicolumn{2}{c}{ Viability \% } \\
\hline \multirow{2}{*}{ Glycerol concentrations } & \multicolumn{2}{c}{ Exposure time to glycerol } \\
\cline { 2 - 3 } $10 \%$ & $0.0 \pm 0.00 \mathrm{Aa}^{*}$ & 48 hours \\
\cline { 2 - 3 } $13 \%$ & $0.0 \pm 0.0 \mathrm{Aa}$ & $40.5 \pm 5.91 \mathrm{Ab}$ \\
$15 \%$ & $0.0 \pm 0.00 \mathrm{Aa}$ & $58.2 \pm 4.57 \mathrm{Bb}$ \\
\hline 168 hours freezing & \multicolumn{2}{c}{ Exposure time to glycerol } \\
\hline Glycerol concentrations & 24 hours & 48 hours \\
$10 \%$ & $0.0 \pm 0.00 \mathrm{Aa}$ & $44.7 \pm 6.23 \mathrm{Ab}$ \\
$13 \%$ & $0.0 \pm 0.00 \mathrm{Aa}$ & $61.2 \pm 10.43 \mathrm{Bb}$ \\
$15 \%$ & $0.0 \pm 0.00 \mathrm{Aa}$ & $50.2 \pm 7.36 \mathrm{ABb}$ \\
\hline
\end{tabular}

* Means followed by the same uppercase letter in the column and by the same lowercase letter in the row did not differ by the Tukey test $(\mathrm{p} \leq 0.05)$. Valor $\mathrm{F}=2.181 ; \mathrm{CV}(\%)=30.47$.

Curran et al. (1992) evaluated cryopreservation for different EPNs species, and found that for isolates of the Steinernema genus, survival was $69 \%$, and for Heterorhabditis, 68\%, after 48 hours exposure to $15 \%$ glycerol, and after 24 hours cryopreservation, and these results are superior to those found in the present work. According to the authors, the concentrations and exposure times to glycerol can be changed in order to optimize the survival of different isolates.

There may be several factors that justify the nonsurvival of some EPNs species to cryopreservation. Among them, it should be noted the cryprotectant concentrations used in the experiment, since they may not have been sufficient to protect IJs and prevent their death after freezing. The other factor is the low efficiency of the glycerol cryoprotectant, since, according to Castro et al. (2011), there are cryoprotectants which have superior ability to penetrate the cell, and which present lower toxicity, when compared to glycerol, such as ethylene glycol, propanediol and dimethyl sulfoxide.

Furthermore, according to Curran et al. (1992), the thawing speed is also a critical step for the success in cryopreservation, since even small delays during thawing may result in a sharp drop in nematodes survivability. However, the authors do not cite the ideal or deleterious thawing times.

With respect to infectivity results, it was observed that $S$. feltiae was able to infect larvae, but there was a decrease in infectivity with IJs cryopreserved in LN for 168 hours (Table 5). Brown e Gaugler (1997) observed a decrease in infectivity in three species of the Steinernema genus after freezing, and suggested that the reduction could be caused by an injury in IJs during freezing. 
Table 5. Percentage of G. mellonella last instar larvae infected by Steinernema feltiae when cryopreserved for 24 and 168 hours, after exposure to glycerol for 48 hours, at different concentrations.

\begin{tabular}{cc}
\hline 24 hours freezing & $\%$ Infectivity \\
\hline Glycerol concentrations & \\
$10 \%$ & $20 \%$ \\
$13 \%$ & $80 \%$ \\
$15 \%$ & $50 \%$ \\
\hline 168 hours freezing & $\%$ Infectivity \\
\hline Glycerol concentrations & $10 \%$ \\
$10 \%$ & $10 \%$ \\
$13 \%$ & $10 \%$ \\
$15 \%$ & \\
\hline
\end{tabular}

\section{Conclusions}

Thus, it is concluded that the species $H$. bacteriophora and $H$. amazonensis do not survive 24 and 48 hours exposure to glycerol at 10, 13 and $15 \%$ concentrations.

S. carpocapsae and $S$. feltiae survive glycerol at 10,13 and $15 \%$ when exposed to it for 24 and 48 hours. Furthermore, glycerol does not influence the infectivity of these species.

Glycerol is effective as cryoprotectant only for S. feltiae exposed for 48 hours at 13 and 15\% concentrations. $S$. feltiae survives cryopreservation for 24 and 168 hours. However, its infectivity is reduced after 168 hours cryopreservation.

\section{References}

ALMENARA, D. P.; ROSSI, C.; NEVES, C. M. R.; WINTER, C. E. Nematoides entomopatogênicos. In: SILVANETO, M.A. C. da; WINTER, C.; TERMIGNONI, C. (Ed.). Tópicos avançados em entomologia molecular. Rio de Janeiro, INCT-EM, 2012. p. 1-40.

ANDALÓ, V.; CAVALCANTI, R. S.; MOLINA, J.; MOINO, A.; MAGALHAES, F. H. Influência da aeração no armazenamento de nematoides entomopatogênicos (Rhabditida) em condições de laboratório. Nematologia Brasileira, Campinas, v. 30, n. 1, p. 45-50, 2006.

ANDALÓ, V.; CAVALCANTI, R. S.; MOLINA, J. P.; MOINO JUNIOR, A. Substrates for storing entomopathogenic nematodes (Rhabditida: Steinernematidae, Heterorhabditidae). Scientia Agricola, Piracicaba, v. 67, n. 3, p. 342-347, 2010.
ANDALÓ, V.; MOINO JUNIOR, A.; ACEVEDO, J. M.; CAVALCANTI, R.; CARVALHO, F. Efeito da temperatura e concentração na sobrevivência de nematoides entomopatogênicos em condições de armazenamento, visando seu uso no controle microbiano de pragas. Boletín de Sanidad Vegetal Plagas, Madrid, v. 31, n. 2, p. 253-266, 2005.

ANDALÓ, V.; MOINO JUNIOR, A.; MAXIMINIANO, C.; CAMPOS, V. P.; MENDONÇA, L.A. Influence of temperature and duration of storage on the lipid reserves of entomopathogenic nematodes. Revista Colombiana de Entomología, Bogotá, v. 37, n. 2, p. 203-209, 2011.

BROWN, I. M.; GAUGLER, R. Temperature and humidity influence emergence and survival of entomopathogenic nematodes. Nematologica, Leiden, v. 43, n. 5, p. 363-375, 1997.

CALEGHIANI, E. C. C.; ARRUDA, R. P.; ANDRADE, A. F. C.; NASCIMENTO, J.; RAPHAEL, C. F.; RODRIGUES, P. H. M. Effects that bovine sperm cryopreservation using two different extenders has no sperm membranes and chromatin. Animal Reproduction Science, Manchester, v. 104, n. 2, p. 119-131, 2008.

CASTRO, S. V.; ANDRADE CARVALHO, A. de; SILVA, C. M. G. da; FAUSTINO, L. R.; FIGUEIREDO J. R. de; RODRIGUES, A. P. R. Agentes crioprotetores intracelulares: características e utilização na criopreservação de tecido ovariano e oócitos. Acta Scientiae Veterinariae, Porto Alegre, v. 39, n. 2, p. 1-17, 2011.

CURRAN, J.; GILBERT, C.; BUTLER, K. Routine cryopreservation of isolates of Steinernema and Heterorhabditis spp. Journal of Nematology, Loudonville, v. 24, n. 2, p. 269-270, 1992. 
FUGA, C. A. G.; FERNANDES, R. H.; LOPES, E. A. Nematoides entomopatogênicos. Revista Trópica: Ciências Agrárias e Biológicas, Chapadinha, v. 6, n. 3, p. 56-75, 2012.

GLAZER, I. Survival biology. In: GAUGLER, R. (Ed.). Entomopathogenic nematology. Wallingford, UK: CABI International, 2002. p. 169-188.

GREWAL, P. S. Anhydrobiotic potencial and long-term storage of entomopathogenic nematodes (Rhabditida: Steinernematidae). International Journal for Parasitology, Oxford, v. 30, n. 9, p. 995-1000, 2000.

GREWAL, P. S.; NARDO, E. A.B. de; AGUILLERA, M. M. Entomopathogenic nematodes: potential for exploration and use in South America. Neotropical Entomology, Londrina, v. 30, n. 2, p. 191-205, 2001.

HAMMERSTEDT, R. H.; GRAHAM, J. K. Cryopreservation of poultry sperm: the enigma of glycerol. Cryobiology, Ottawa, v. 29, n. 1, p. 26-38, 1992.

JAMES, E. R. Cryopreservation of helminths. Parasitology Today, New York, v. 1, n. 5, p. 134-139, 1985.

KAYA, H. K.; STOCK, P. Techniques in insect nematology. In: LACEY, L. (Ed.). Manual of techniques in insect pathology. New York: Academic Press, 1997, p. 281-324.

MAHMOUD, K. G. H. M.; SHOLKAMY, T. H.; AHMED, Y. F.; SEIDEL, G. E.; NAWITO, M. F. Effect of different combination of cryoprotectants on in vitro maturation of immature buffalo (Bubalus bubalis) oocytes vitrified by straw and open-pulled straw methods. Reproduction in Domestic Animals, Malden, v. 45, n. 4, p. 565-571, 2010.

MOLINA, J. P.; LOPEZ, N. J. C. Producción in vivo de três entomonematodos con dos sistemas de infección em dos hospedantes. Revista Colombiana de Entomología, Bogotá, v. 27, n. 1-2, p. 73-79, 2001.
NUGENT, M. J.; O'LEARY, S. A.; BURNELL, A. M. Optimised procedures for the cryopreservation of different species of Heterorhabditis. Fundamental Applied Nematology, Leiden, v. 19, n. 1, p. 1-6, 1996.

OHBA, K.; ISHIGURO, T.; HAYASAHI, Y. Freeze-thaw survival of the entomogenous nematodes Steinernema feltiae and $S$. glaseri in brief comparison with survival of Caenorhabditis elegans and Aphelenchus avenae. Japanese journal of nematology, Tokyo, v. 18, n. 1, p. 30-35, 1989.

PEGG, D. E. Cryopreservation and freeze-drying protocols methods. In: DAY, J. G.; GLYN, N.; STACEY, G. N. (Ed.). Molecular biology. Totowa: Humana Press, 2007, p. 39-57.

POPIEL, I.; VASQUEZ, E. M. Cryopreservation of Steinernema carpocapsae and Heterorhabditis bacteriophora. Journal of Nematology, Loudonville, v. 23, n. 4, p. 432-437, 1991.

SHAPIRO-ILAN, D. I.; GOUGE, D. H.; PIGGOTT, S. J.; FIFE, J. P. Application technology and environmental considerations for use of entomopathogenic nematodes in biological control. Biological Control, Boca Raton, v. 38, n. 1, p. 124-133, 2006.

TRIANTAPHYLLOU, A. C.; MCCABE, E. Efficient preservation of root-knot and cyst nematodes in liquid nitrogen. Journal of Nematology, Loudonville, v. 21, n. 3, p. 423-426, 1989.

WHITE, G. F. A method for obtaining infective nematode larvae from cultures. Science, Washington, v. 66, n. 1709 , p. 302-303, 1927. 
